特集記事

\title{
可視化情報シンポジウム 40 周年記念パネルディスカッション Panel Discussion for the 40th Anniversary of Visualization Symposium
}

\author{
パネリスト：谷田 好通（東京大学名誉教授）, 中山 泰喜 (未来技術研究所所長), \\ 大島 裕子 (元 (株)リコー), 小林 敏雄 (日本自動車研究所所長), \\ 川橋 正昭 (埼玉大学特任教授), 岡本 孝司 (東京大学教授)
} 司会：伊藤 慎一郎 (工学院大学教授)

2012 年 7 月 24 日, 第 40 回可視化情報シンポジゥム の特別行事として，40 周年記念パネルディスカッショ ンが工学院大学新宿キャンパスにて開催された。本学会 を創設期から現在まで長きに渡り支えて頂いた先生方を パネリストとしてお迎えし，学会の歩んできた歴史につ いてご講演頂いた。ここでは，各先生方のご講演を紹介 する．全てのお話を紹介することは紙面の都合上できず, 一部省略されている旨はご容赦頂きたい。なお，文章は できるだけ先生方の口語に近い状態で, 図は先生方の講 演資料より抜粋させて頂いた。読者に少しでもその場の 雲囲気を感じ取って頂ければ幸いである。

\section{1. 谷田好通先生}

ご紹介預かりました谷田でございます。本来から言い ますと，トップバッターは浅沼強先生がなされるべきだ と思います。浅沼先生は, 流れの可視化シンポジウムを 創設された方で, 流れの可視化学会の初代会長を務めら れた方ですが，今日は体調を崩しておられまして出席で きませんので，その代わりといっては何ですが，私がや らせて頂くということでご容赦頂きたいと思います。今 日，紹介する内容は，流れの可視化のシンポジウム創設 から流れの可視化学会が設立されるまで, 1973 年から 80 年頃までにかけての色々な話をさせて頂きたいと思 います。

振り返ってみますと, 流れの可視化は色々な方面に 渡って長年やられていますが，1970 年頃までは, Fig. 1 に出ているような手法が大勢を占めていたわけです.

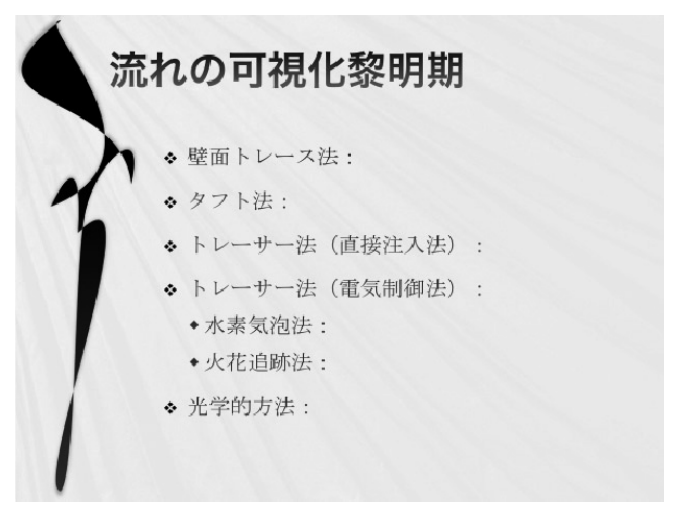

Fig. 1 黎明期における可視化手法一覧
現在は，コンピュー夕を使った技術がかなり大きな部分 を占めておりますが，1970 年まではこういう技術が主 流でした。それらがいつ頃から始まったかを調べてみる と，壁面トレース法は 1940 年代頃に色々とやられてお ります。それから，タフト法は 1928 年頃に使われてお りまして, 日本では 1941 年にお茶の水大の坂上治郎先 生がたんぽぽ風向計という非常にユニークな測定技術を 開発されております。このたんぽぽ風向計というのは, $10 \mathrm{~cm} / \mathrm{s}$ 程度の微風でも重力の影響なしにタフト法を使 うことができるという，非常に優れた方法であります。

トレーサ法の直接注入法というのは，これは皆さん学 生時代から教科書等でご存知の Reynolds が色素流脈法 で管内の乱流遷移の存在を解明しており（1883 年），そ れから Prandtl と Tietjens, これも教科書で，アルミ粉 を使ったきれいな写真（1941 年）が紹介されておりま す。日本でも, 1927 年に, 富塚清先生, この方は航空 原動機の権威であったわけですけど，夕バコの煙とかマ グネシウムパウダーを使って風洞の中の流れを観測して おられます。1927 年ですから，かなり古くからこう いった可視化技術が使われてきたということです。卜 レーサ法の，もう一つの電気制御法は，電気制御という こともありやや時代が遅くなっておりまして, 水素気泡 法は 1955 年に Geller がテルル法から思いついたといわ れております. 1960 年代から 70 年代にかけて, 浅沼先 生, 九大の種子田先生, 東海大の中山先生, それから米 スタンドード大の Kline 先生ら, 多くの方が水素気泡法 を使って優れた論文を発表しておられます。炎花追跡法 は割と古くから開発されているようで，1932 年に Townsend が境界層速度分布を調べています。1947 年 に北大の佐伯先生が火花時間間隔制御を研究しておられ て，かなり古くからこういう研究もあったんだなという 風に思うわけです。やはり 1960 年代から 70 年代にかけ て, トヨタの加治屋さん, それから東海大の中山先生, 東大の浅沼先生，その他の方々が盛んに火花追跡法を利 用して研究しておられます。

光学的方法は，これはもう申し上げるまでもありませ んが，19 世紀の中頃からジャーマン干渉計，シュリー レン法, マッハ・ツェンダー干渉計といったものが次々 と開発されて広く使われております。 
こういう可視化技術というのは，個々の研究者が努力 を重ねて技術を開発してきたということなんですが，そ れを総合的に体系化するという試みとして一番最初に行 われたのが 1960 年の ASME の流れの可視化シンポジ ウムで, Kline 教授が中心になってやられたものです. そのシンポジウムで, Kline 教授が開会の辞で主として 流体力学掞よび関連分野における科学的な解析, および 工学的な解析に, 流れの可視化というのは非常に有用で あると述べて扔られます。

ここで「Flow visualization」，日本語で「流れの可視 化」というのがその後盛んに使われるようになったわけ ですが，この「流れの可視化」という言葉がいつ頃から 使われていたのかというのが，ちょっとはっきりしない ところがありますが，どうも岐皁大の松井辰弥先生が初 めて「流れの可視化」という言葉を使われたようです. 松井先生は, 乱流境界層の問題を流れの可視化を使って 研究しておられるわけですけど，英文で書かれて，それ を日本の場合には博士論文を出す場合には和文に訳した ものを出さなければいけないということがありまして, Flow visualization をどういう風に訳すか大変苦労され, 結局「流れの可視化」という言葉がいいのではないかと 思いつかれてそれを使われたそうで，それが最初だと言 われております。

1968 年にやはり Kline 先生が乱流境界層の計算法に 関する会議を開かれて,「流れの可視化」というものが, 熱線流速計の相関測定と同程度に有用で, 現象解析やモ デル構築に重要な役割をもっているということを示され ております。そういう流れの中で, 1972 年にチェコの Reznicek 先生（国際シンポジウム等で活躍されていて ご存知の方もいるかと思います）が，単行本をチェコ語 で出されました，それから，74 年にドイッのボッフム 工科大学の Merzkirch 先生が, 流れの可視化という単 行本を出して扔られます。このように, ASMEのシン ポジウムからはじまって, 流れの可視化の単行本が出版 されるようになって次第に体系化されてきたわけですが, この単行本というのが，中身を見ますと，どちらかとい うと欧米の方は光学的な手法が主流であって, それがか なりの部分を占めており，その他の部分は載ってはいる のですが，十分ではない，それで，それらを網羅して体 系化していこうじゃないかという話が出まして, 1973 年に流れの可視化シンポジウムが創設されました，その 後, 1977 年に流れの可視化ハンドブックが出版され, 同じ年に流れの可視化国際シンポジウムが創設され， 1981 年には流れの可視化学会が設立されたということ です.

そこで, 流れの可視化シンポジウムが創設された経緯 を少し述べさせて頂きますと, 東京大学の航空研究所, これは大正年代から航空研究の中心として存在していた わけですけど, その後, 東大生産技術研究所のロケット 部門，これは有名な糸川先生が中心になってやられてい

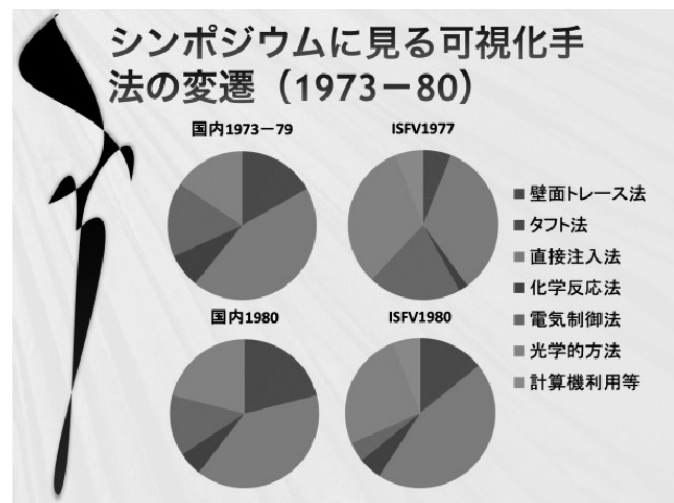

Fig. 2 国内外シンポジウムでの可視化手法の変遷（1973-80)

たわけですけど，それと，その当時盛んに発展していた 宇宙科学部門とを併せまして, 東京大学宇宙航空研究所 が設立されました，宇宙航空研究所というのは，全国の 共同利用研究所でありまして, それを利用して, 浅沼強 先生, 宇宙航空研究所の教授であったわけですが， 2 年 間ほど熟慮に熟慮を重ねたというお話なんですが，流れ の可視化シンポジゥムを開催してはどうかという提案を されまして，1972 年に設立準備会が結成されました。

そのシンポジウムの背景を少し説明しますと，これは 先ほどからも申し上げているように，流れの可視化技術 をより利用しやすく体系化したい，それから，可視化技 術というのは広い分野にわたっておりますので, 情報交 換を活発にして相互の親睦を眓るということです。それ から共同利用研究所の一つのメリットとして，それに対 する出版費用とか出張費用が支給されるということです. その第 1 回流れの可視化シンポジウムの準備会が, 1972 年 10 月 17 日に開かれております。シンポジウムの開催 具体案の中で関連分野として広い範囲が挙げられていま すが，この中でちょっと注目されますのが，この当時， 発展途上のバイオメカニクスが含まれており，これが現 在の可視化情報学会の一つの大きなジャンルになってお り，その元になっているのではないかと思います。

第 1 回シンポジウムの世話人は浅沼先生と生研の石原 先生の押二人でした。第 2 回準備会, それから第 3 回準 備会とありまして, 1973 年の 7 月 12 日と 13 日, 東大 宇宙航空研究所の講堂で流れの可視化シンポジウムは開 催されました. 論文数が 36, 参加者数が延べ 697 名で, 平均しますと 1 日あたり約 350 名になるわけですが, 講 堂が 120 名くらいしか収容できないので, 数字だけみま すと 3 回転しないと入りきれないというぐらいの方がい らっしゃり, 立見席があったというぐらいで, 狭い講堂 に入口が一つしかないというので，何かあった時にはど うするか，避難対策といいますか，そういったことを浅 沼先生あたりがだいぶ御心配になったという話を聞いて おります。

そういったことで, 第 1 回シンポジウムが東大宇航研 講堂で開催されましたが, 会場が狭いということで 2 回 目は東大生研講堂, それから, 3 回目からは東大工学部 
大講堂で開催されております。それで, それぞれのシン ポジウムで非常に多くの参加者があったわけですが，東 大工学部の大講堂というのは, 階段教室なんですけど, 冷房が効かず，真夏の暑いさなか汗をかきながらシンポ ジウムを行ったという懐かしい記憶がございます.

それで, 昭和 50 年には, 流れの可視化シンポジウム は非常に成功であるので体系化してもらいたいという要 望がありましたものですから，それではハンドブックを つくることを考えてみようじゃないかということで, 1975 年には流れの可視化ハンドブック編集委員会が発 足致しまして，2 年後，1977 年には流れの可視化ハン ドブックが朝倉書店から出版されております。

その 1975 年にはもう一つ, 流れの可視化シンポジウ ムに論文が非常に多く寄せられ，また外国の方が出席さ れることがありましたので, それでは国際シンポジウム も考えてみたいということで, 流れの可視化国際シンポ ジウムの東京開催が検討されまして委員会が翌年に発足 致しました. 1976 年に浅沼先生が欧米に出張されまし て, そのときに色々な大学・企業で, 国際シンポジウム への協力を要請されました。それを受けまして, 1977 年に第 1 回流れの可視化国際シンポジウムが東京霞が関 の国立教育会館で行われました.

このように順調に発展してきたわけですが, 1979 年 頃になりまして, 東大の宇宙航空研究所が改組されるこ とになります。これはどういうことかといいますと, 先 ほど申し上げましたように, 宇宙航空研究所は航空と宇 宙の寄合世帯でしたが，宇宙関係の予算が非常に膨大な ものになり, ロケット打ち上げなどのプロジェクト研究 は大学にそぐわないのではないかという話になりまして, そういった宇宙工学, 宇宙科学というものを外部に出す という話が出てきました，そういうことで宇宙航空研究 所が改組されますと, シンポジウムを継続することがで きないものですから, どう継続するかという問題を, ア ンケートをとったり，各学会に発信したりと色々と検討 致しまして, 流れの可視化学会を設立するのが一番良い のではないかということで, 浅沼先生が代表となって, シンポジウム準備委員会が学会設立準備委員会に移行し まして, 1981 年に流れの可視化学会が設立されました。

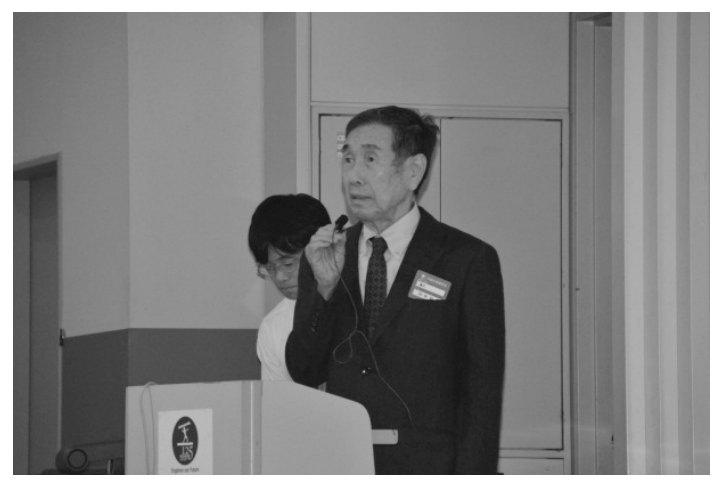

Fig. 3 講演中の谷田先生
初代会長には浅沼先生が就任されました。

ついでに，宇宙航空研究所がその後どうなったかとい いますと，1981 年に二つに分かれて，一つは宇宙航空 研究開発機構（JAXA）に，もうひとつは東大の先端科 学技術研究センターになっております。先端研の方は, 新しい組織でありまして, 航空研究所とは関係のない組 織となっているわけです。そういう風に，ほとんどギリ ギリのところで可視化学会が設立されてきたわけです.

この間, シンポジウムでどういう可視化技術が使われ てきたか, その変遷をちょっと調べたのですが, 1973〜80 年の分を円グラフにしたものが Fig. 2 で, 左 が国内シンポジウム, 右が 1977 年と 1980 年の国際シン ポジウムですが，直接注入法がいずれの場合も $40 \%$ を 占めております。これを見ますと，国際シンポジウムの 方がどちらかというと光学的な手法が多いという風に考 えることができます。それから，1980 年代頃までは， コンピュータ関係というものがほとんど使われておりま せんで，国際シンポジウムに数編，コンピュータ関係が 出ているだけです。これは最近コンピュータ技術がかな り主要な部分を占めていると思いますので，それがどう いう風な形になっているかを比較すると面白いと思いま す.

そういうことで, 1973 年から 80 年の 8 年間くらいの 間で, シンポジウムを設立して学会を創設, その間にハ ンドブックを出版し，国際シンポジウムを行うというよ うな，非常に猛烈な勢いで前進してきたわけですが，そ れがどうして日本でなされたかということについて，ミ シガン大学の Wen-Jei Yang 先生が, 流れの可視化学会 設立の祝辞の中で四書の中の孟子の言葉を引用しておら れます。即ち，天の時は地の利にしかず，地の利は人の 和にしかず (天時不如地利, 地利不如人和), それをや さしく表現しますとこういう形になるかと思いますが， 事業を成功させるにはそれぞれが必要なわけですけども 人の和というのが一番大切だと. 外国のシンポジウムの 色々な経験から見ますと, 外国の方はどちらかというと 個人の人脈を中心にして成されることが多いようですが, それに対して日本の方は, 全国的なネットワークを作り 上げて，それで仕事を進めるという違いがあるようです。 日本において流れのシンポジウムが成功し学会設立に 至ったのも人の和のおかげでしょうし，その他のハンド ブックも人の和が一番大きかったと思っております。こ れを結びの言葉としまして, 講演を終了致します。

\section{2. 中山泰喜先生}

ご紹介頂きました中山でございます，谷田先生は流れ の可視化学会についてお話しをされました，私は，それ から法人化を含めまして, 可視化情報学会の設立と学会 の社会貢献に関してお話ししたいと思います。

まず可視化情報学会の設立に関しまして, 法人化の要 件等から順次ご説明していきたいと思います．法人化の 


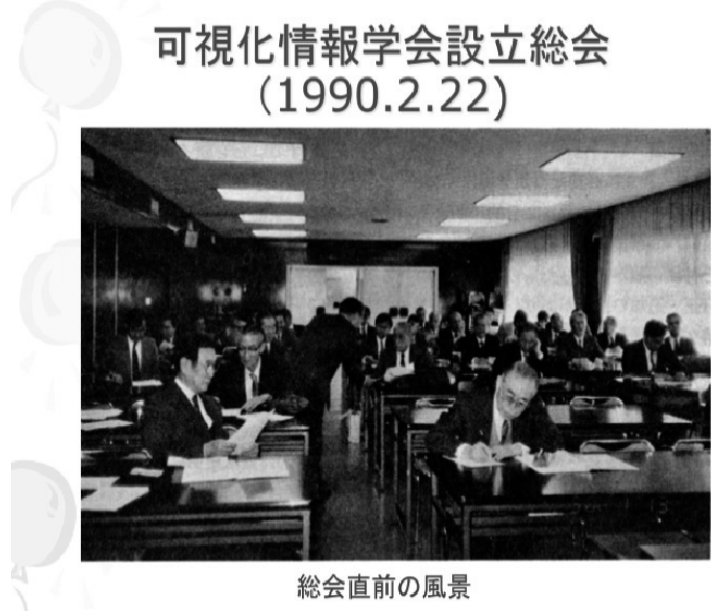

Fig. 4 可視化情報学会設立総会直前の様子

要件に関しては, 当時どういうことだったかというと, 1）学会員 1000 名以上，2）資本金 2000 万円以上，3） 運用財産 1000 万円以上，4）独立した事務局を有するこ と，5）定款を有すること，6）学会誌を定期的に出して いること，7）学会としての存在意義があること，そう いうような条件でございました.

1987 年の 1 月に法人化推進特別委員会が設置されま した。ちょうど今から 25 年前です。それに先立ち, 1984 年 1 月に独立の学会事務局を新宿区に設置いたし ました. 1987 年 6 月には会員数は 1142 名，資本金 2000 万円を超えましたので，設立趣意書，収支決算書，事業 報告, 事業計画, 会員数, 財産目録, など 14 種類の法 人化のための提出資料を文部省（現文部科学省）に提出 して法人化のスタートを切りました．あとは学会内容の 検討ということで文部省から様々な質問を受けまして, それに対して沢山の説明書を提出した記憶があります.

次に学会名称の検討に入りましたが, その当時学会の 担当分野が大きく拡大いたし，流れの可視化はもちろん 重要ですが, 熱とか音とか, 電磁気とか化学変化などに 関する可視化手法, 特にコンピュータを利用した可視化 法が拡大しましたので 1988 年 11 月に新しい学会名称を 募集し, 多くの方々の賛同を得まして, 1990 年 1 月に 臨時総会を開いて, 可視化と情報を一緒にしまして, 正 式に可視化情報学会, と決定いたしました。 それで,い よいよ，法人設立の申請でございますが，1989 年 10 月 に民法による法人設立に必要な重要項目よりなる書類な どを提出致しました，その後，度々訂正・追加の指示が ありまして, その間, 第 1 次, 第 2 次審査会がありまし て, そして，1990 年 1 月 19 日に文部大臣に社団法人可 視化情報学会設立許可申請書を一式提出しました。そし て, 1990 年 2 月 1 日付けで石橋一弥文部大臣より法人 設立許可証を頂きまして，ここに社団法人可視化情報学 会が正式に発足いたしました.1990 年のことです。最 初の会長はさきほどお話しをされた谷田先生に第 1 回の 会長を務めて頂きました。そして, 1990 年 2 月 22 日に
可視化情報学会設立総会 (1990.2.22)

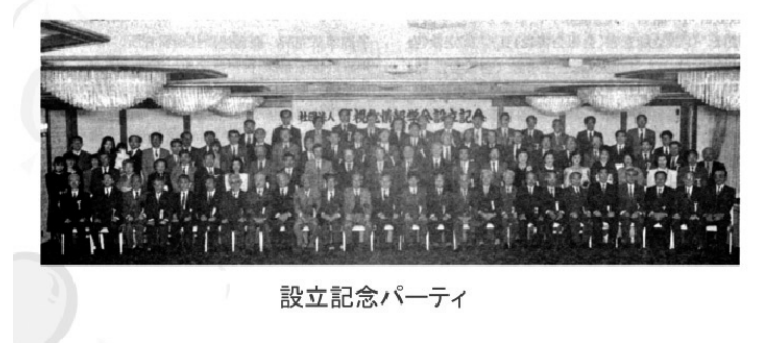

Fig.5 設立記念パーティーの様子

可視化情報学会設立記念パーティーが霞が関ビル 33 階 の東海大学校友会館の阿蘇の間で盛大に行われました. これは, その総会の前に控室で集まってくださった方々 です (Fig. 4 ). パーティーでは多くの来賓の方々から 祝辞を頂きましたが，当時の文部省の学術情報課緒方邦 夫課長は次のように述べられました，色々なことはこの 文部省学術情報課でやってくださいまして大変お世話に なりました。その祝辞を書いてきました。「法人化まで の経過は山あり谷ありだったが，その間，我々の度重な る質問に対して, 正しく, しかも, 誠実に答えてもらっ た. 足掛け 4 年に渡る長い期間を途中で諦めず，法人化 に努力する学会は数少ない. 心から祝辞を述べたい. 今 後は，幅広い活動を通して量的・質的発展を期してもら いたい」と，我々の気持ちをよく汲み取られた立派な御 挨拶を頂きました。

思い起こしますと, その間, 文部省に出頭したのが 50 回を超えました。提出した書類は高さ $1 \mathrm{~m}$ を超すと 言われています。この作業は，ほとんど，東大 8 号館 2 階の田古里先生の部屋で行われました．私は大学を終え ると, 田古里先生の部屋に行って作業を続けることが 度々でした。終電を逃してタクシーで带ったこともよく あったと記憶に残っております。それから，文部省にも 50 回以上行ったので守衛さんに私の顔を覚えて頂き, いつも挨挨拶してくださるまでになりました.

もう一つ，今にも関係することですからお話しておき ますと，法人化するにあたって，緒方課長から「一般の 学会は縦割りである. 可視化情報学会はこれらを横につ なぐ学会として活動して頂きたい」との言葉を頂きまし た.このお言葉は私の記憶にも強く残っております。そ ういう方向で現在も活動が行われております．次に，こ れが記念パーティーの後の集合写真です (Fig. 5 ).こ ういう風に沢山の方が集まってくださいました.

次の話題としては, 学会の社会貢献について簡単に申 し上げたいと思います。それは，見えない流れの世界展， 見えないものを視る科学展, 流れのファンタジー出版, 文化フォーラム，こういうことだと思います，見えない 


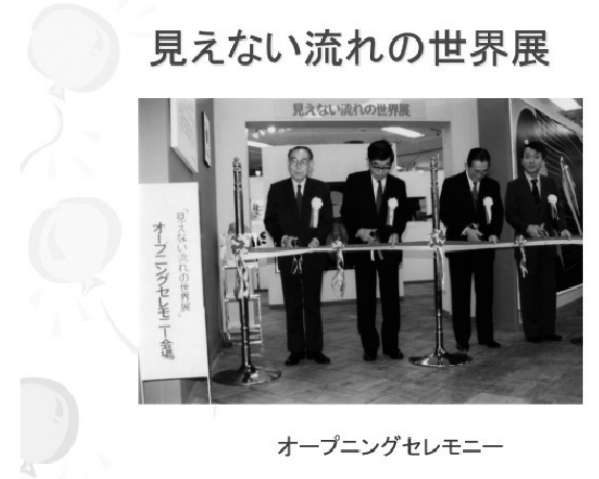

Fig. 6 見えない流れの世界展（1986 年）

流れの世界展というのは流れの可視化学会創立 5 周年を 記念して，可視化技術を総合したものであり，淺沼先生 を委員長として，1986 年 10 月 10 日から 15 日まで 6 日 間西武百貨店池袋店の 7 階の大催事場で開催されました. その趣旨は一般の方々に流れの可視化を知ってもらうこ とでしたので, 展示会では私達の生活環境の中にある 色々な流れを, その対象に適した手法で可視化し, 色々 な角度から分析した例を紹介して, 流れの可視化が私達 の生活や産業にどのように役立っているのかに興味と関 心を持って頂けるよう努力しました.

会場には写真コーナー, ビデオコーナー, パソコン コーナー, 実験コーナー, 販売コーナーなどを設けまし た。この写真 (Fig. 6 ) はオープニングセレモニーの テープカトをしているところです，手前が私．その隣に 今井先生, その次が浅沼先生, 一番向こうの方は, 西部 百貨店の責任者の方でございます，入場者は 6 日間で 12,686 名と, 大変盛況でした。

次はもっと大きな可視化展をやりました。これは是非 聞いていただきたいと思います。可視化シンポジウムの 20 周年を記念しまして, 見えないものを視る科学展を 1992 年 8 月 17 日から 29 日までの 2 週間, 新装なった 三越美術館（新宿）で開催しました。それは，可視化情 報学が, 流ればかりではなく, 熱, 燃焼, 振動, 化学反 応, 電磁気などの可視化にまで及びまして, コンピュー 夕の驚くばかりの発展により, 様々な現象の数值シミュ レーションが可視化できるようになり，コンピュータグ ラフィックスの多彩な画像表現と相まって更に新しい領 域が広がりつつある状況にありました。これに鑑み，技 術者や専門家ばかりでなく, 広く多くの方々, 特に青少 年の皆様に可視化情報学とは何かわかっていただき，そ の成果について関心と理解を深めていただきたいという 趣旨の基に開催いたしました。

朝日新聞社, NHK プロモーション, 三越に協力をお 願いしまして快諾を得ました。

今から考えると夢のような話ですが，経費は特別記念 事業資金に加えて企業に全面的に打願いしまして, 豊田 自動車の全面的な協力が得られ, 東芝, オリンパス光学, 日本電気, 日産自動車などが続いて協力頂きました。 そ

\section{見えない流れの世界展}

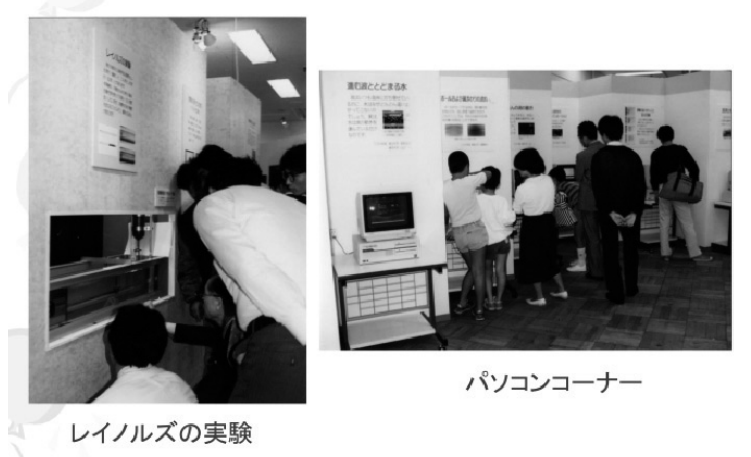

Fig. 7 見えない流れの世界展 (1992 年)

の他の企業も加わっていただきまして, 総額 8000 万円 の資金を集めることができました。朝日新聞に大きく報 道され, 3 月 21 日には NHK 総合テレビから朝 8 時の タウン情報として放映され，3 月 25 日 NHK ラジオ第 1 で生放送が行われました。 その他新聞や雑誌にも色々 と報道されました。

三越の会場は $1200 \mathrm{~m}^{2}$ り, 写真 (Fig. 7 ) はその展 示内容の一部ですが, これは Reynoldsの実験で一般の 方に流体に対して親しみをもって頂けました。 それから， パソコンコーナー, それから, 人体関係ですね, バイオ, その次は先端技術に支えられた未来車コーナー, トヨ夕 はこの展示会のために 3500 万円を使ったと聞きました が, 未来車を 2 台展示してくださいました、ゴルフボー ルの科学に関するものや, 色々な流れの現象に関して一 般の方々に興味を持って頂けるよう努力いたしました。

入場者は約 32,400 名で, 若い人の入場者が多かった と記憶しております。

あとは流れのファンタジー，これは著著ですね。第 6 版までいって, ブルーバックスは 1 回の刷りの数が多い ですから，たくさん売れました，最後，文化フォーラム ですが，今も続いております。第 1 回目は 1997 年 10 月 ですが, 東京の工学院大学と共同で行わせて頂きました。 その時は, 850 名の申込及があり, 150 名のお断りの手 紙を出すほどの盛況でした，持時間のようですので, 以 上でございます．本日はどうもありがとうございました。

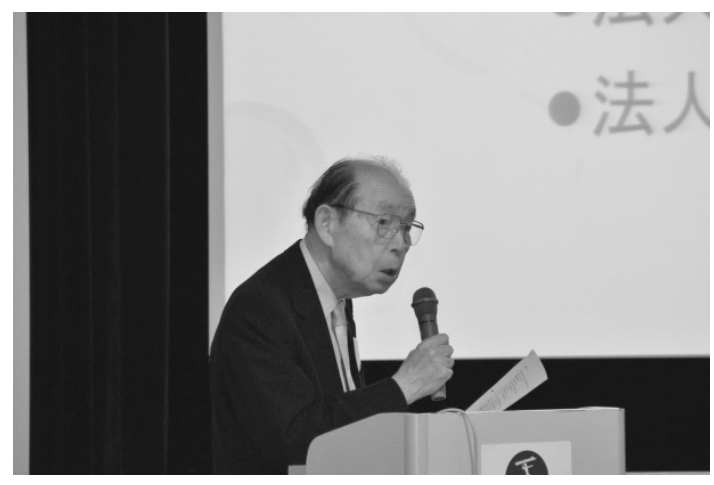

Fig.8 講演中の中山先生 


\section{学 会 誌 (1 126号)}

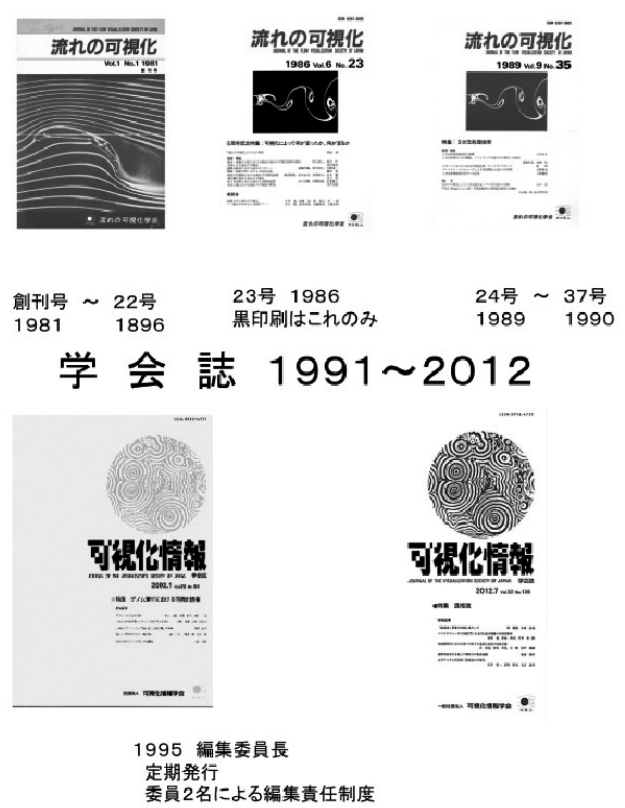

Fig.9 学会誌の表紙の変遷

（上段：1981～1990 年，下段：1991 年～現在）

\section{3. 大島裕子先生}

大島でございます。私が今日お話しするのは学会誌に ついてですが、先ほど谷田先生からお話のありました， 第 1 回流れの可視化シンポジウムの 36 編の発表の 1 つ に私のものもありました。そのときは宇宙研の会場の一 番後ろに座席にいたのですが，前の演台に行くまでが通 路が人であふれて狭くとても大変でした。

さて, 可視化情報学会の学会誌ですが, 可視化シンポ ジウムから流れの可視化学会になってから谷田先生, 小 林先生, 岡本先生, 安藤先生の編集委員長のときに, 私 は委員を仰せつかり，学会誌出版のお手伝いをさせて頂 きました，これが創刊号です (Fig. 9 上段左). 22 号ま で同じ表紙で, 中口博先生の翼周りの流れの煙による写 真です。その次に黒い表紙が 1 冊だけあるのです（Fig. 9 上段中). これが種子田定俊先生の電解法で撮られた カルマン渦の写真です。 その後, 写真は同じですけれど も，24号から 37 号まで青い表紙でした。 その次の号か ら「可視化情報」として今の表紙 (Fig. 9 下段) になり ました。私は 1994 年にシンポジウム委員長，その翌 95 年に編集委員長を仰せつかりました。ところが編集委員 長になって，会誌がそれまで定期的に発行されておらず， 3 週間や 1 月遅れがよくあることがわかりました．先ほ ど中山先生もおっしゃったのですが, 文部省の学会設立 条件として, 学会誌の定期発行がその 1 つだったのです。 それで何とかしようと, 前の幹事の藤枝さんと相談しま した. 10 名以上いる委員を， 2 人ずつ組にして 1 冊を担 当していただくようお願いしました． 2 名の委員による
編集責任制度です，次の委員会には，2 人ずつ全部の組 がきちんと案を持ってきてくださいました。それ以来, この編集委員責任制度が機能し, 定期発行となりました。 先ほど飯田先生に伺ったのですが，今もそうだとのこと です. 1995 年以来, 1 度だけ 1 週間遅れたことがあり ますが，もう 17 年間も，多分これからもずっと私の提 案が続くのではと思っております。これは（Fig. 9 下段 右）先日届いた最新号なのですが，6月 26 日に私の手 元に届きまして，7月 1 日発行にちゃんと間に合ってお ります.

また、1995 年にはコスト削減のため, 印刷所を創刊 号から編集，印刷，発酵をお願いしてきた精機通信社か らニッセイエブロ社に変更しました，原稿は手書きから ワープロとなり，ディスクでの受け渡しとなりましたが (まだメールは普及していない)，ニッセイエブロ社では 文章の編集は行わず著者責任となりました.

さて，次にホームページのことをお話しします（Fig. 10). 私が編集委員長になってから,リコーの副社長を していらした尾上守夫先生（この会場に見えてます）よ り,この会誌の映像などをホームページに載せたらいい と指示を頂きました。「ホームページって何ですか？」 「君知らないの? 」と言われ，教えて頂いたのです. サーバーとしてはリコーのネットメセナを使ってよいと のこと，私もない知恵を絞り。理事会に提案したところ， 皆様から「ホームページとはなんですか？」と誰もご存 じない.その挙句に「お金はかかるのか？」と言われま した。お金はいらないこと，労力は担当委員と私があた ることで許可となり，ホームページができました．学会 の概要やお知らせなどを載せ発足しましたが，学会誌の 口絵を入れるなど，工夫は致しましたが，私がよく躓き まして，そのたびに尾上先生に助けて頂きました。ホー ムページを毎号更新するのは結構大変な仕事でした。そ のあと 1998 年の法人化 10 周年のときの会長が, NEC の吉川英一さんで, NECで新しいスタイルで作って下 さいました。 そのときに，入会案内や口絵，論文のアブ ストラクトもはいり，この頃には学会の出版物だけでな く，色々なデータベースまで入っています。もう皆さん

$$
\text { ホームページ }
$$

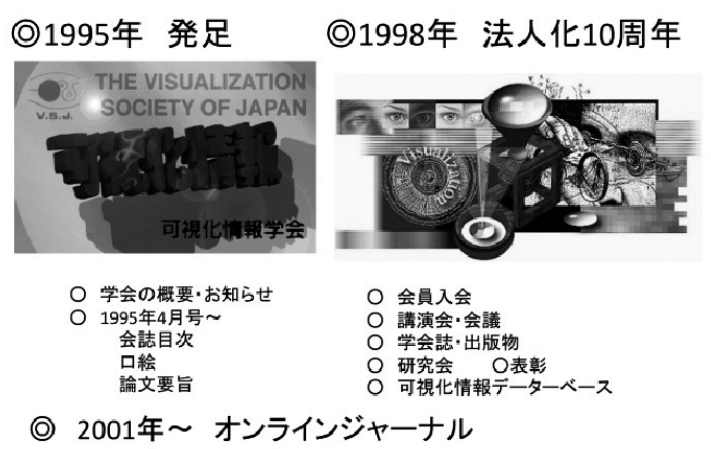

Fig.10 学会ホームページの歴史 


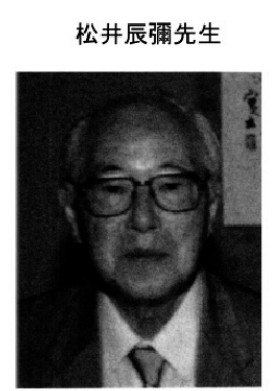

2010年9月4日 93墭

Visualization $\rightarrow$ 可視化
種子田定俊先生

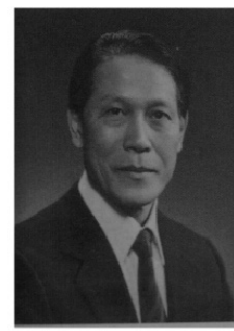

2011年6月10日 86 歳

電解法 カルマン渦

画像から学ふ流体力学 [朝㕣害店]
Fig.11松井先生(左)と種子田先生(右)

ご存知かと思いますが，この間久しぶりに見ましたら， 現在のホームページの表紙は，動画になっています。一 応ここまでで, 学会誌についての話は終りですが、少し 別な話をさせて頂きます.

皆さん, 可視化情報学会では, 何の抵抗もなく「可視 化」と言っていますけれども，まだ国語辞典に「可視 化」という言葉が載ってないのはご存知ですか？2006 年の広辞苑の第 6 版で「可視」をひきますと,「肉眼で 見ること，例えば可視光線」としか書いてありません. その次はカジカになってしまいます (会場笑).それか ら色々の辞書を調べたのですが，「可視」「目で見るこ と」しか書いてない. 1995 年の岩波の科学事典に「可 視化」とあったのがはじめてす。20世紀はそれだけで す. 英語の辞書として, 研究社の英和辞典では visualization は, 「目で見ること」とあり, 可視化の訳は出て おりません。逆に和英辞典で可視を引いたら, visualization, 例えば flow visualization, 流れの可視化と出て おりました。

先ほど谷田先生のお話にあったように，松井先生が最 初に可視化という visualizationの和語を使われた方で す。実は谷一郎先生のところに, 1960 年に提出された 学位論文が英文であり。それを和訳するのに, 谷先生と 松井先生が考えられて,「可視化」という言葉が生まれ たのです. 最近, 私達の学会だけではなくて, 可視化と いう言葉が使われています, 裁判にまで可視化が出てき て，私はあまりよい気持はしておりません。松井先生は 1978 年に日本の流体力学者 20 人で中国に相互交流のた めに行かれました. そのときは, 中国では可視化とは言 わないで，「顕示」とあったそうです。松井先生が州国 後,「顕示の方が良かったかもしれない」と言われたの を覚えております。今では中国でも「可視化」です。日 本の技術が進んでいたからだと思います，「可視化」は 今は一般化されておりますが，言葉として，音だけで字 に結びつかず，ピンとこなかったのです，実は私自身も， 可視化の研究をやっていますというと,「どんなお菓子 を作るんですか」と言われたことが何度かありました
(会場笑).

松井先生は一昨年に 93 歳で亡くなられました。私は 長年親しくお付き合いさせて頂き、亡くなられる前まで お便りを頂いておりました。 また，種子田先生は去年の 6 月に亡くなられました。私が学部学生の時に初めて学 会に行ったのですが，他の先生の数式いっぱいのお話は 何にも判らなかったのに，このお二人の講演だけは，映 像もあり理解できたのを覚えております。可視化で大変 お世話になりましたので，この機会をお借りして哀惜の 情を込め偉大な大先輩お二人を皆様にご紹介いたしまし た (Fig.11).

\section{4. 小林敏雄先生}

ご紹介頂きました小林でございます。えーと，だいぶ 時間が過ぎているようで. しかも谷田先生，中山先生か ら, 国際学会, 特に ISFV のはじまりについてはいくつ かお話がありました。簡単にいきたいと思います。

これは流れの可視化学会が, あ, 失礼, 可視化情報学 会が主催する主な国際シンポジウムであります。現在も 続いているものもありますし, 一回限りのものもござい ました、えー，この話をせよ，ということを言われまし たときに, 少し, 学会の今までの開始の時期を調べてみ ました. 可視化情報学会が関与しております学会のうち, 特に大きいのは 4 つでございますので，その 4 つについ て紹介したいと思います。

まず最初は ISFV (International Symposium on Flow Visualization) です.2012 年に第 15 回が終わったとこ ろです。ここまで参りました(Fig.13). 1 回目が 1977 年. 6 回目と 10 回目に日本で開催しておりましして, 16 回目も日本で開催予定であります。これの特徵は, 1977 年 10 月 12 日に第 1 回を開催したわけでございま すけれど，その準備は 2 年半を要しております。 1975 年に, 春のことだったと思いますけども, 流れの可視化 シンポジウムの準備委員会がございまして, そこで, 国 際会議を立ち上げたらどうか, という話になり，比較的 民主的な学会でございまして，1975 年の夏に恒例の国 内のシンポジウムがございました。 そこで, 参加された 皆様にアンケートを実施しました。国際シンポジウムを 開催すべきか, 見送るべきか, そういうアンケートをと

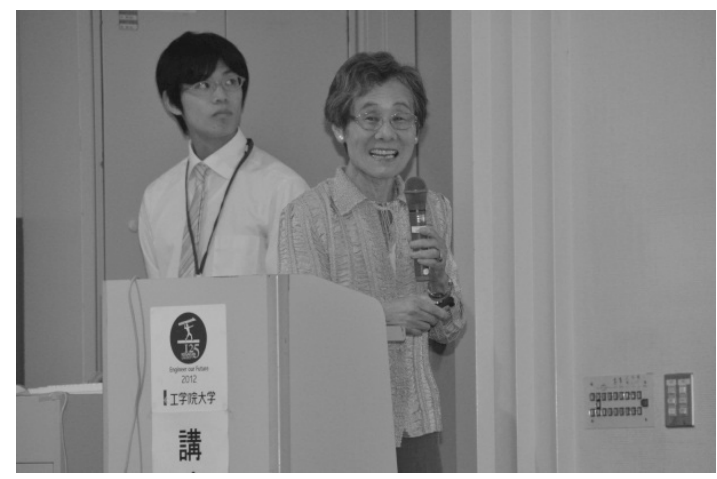

Fig.12 講演中の大島先生 


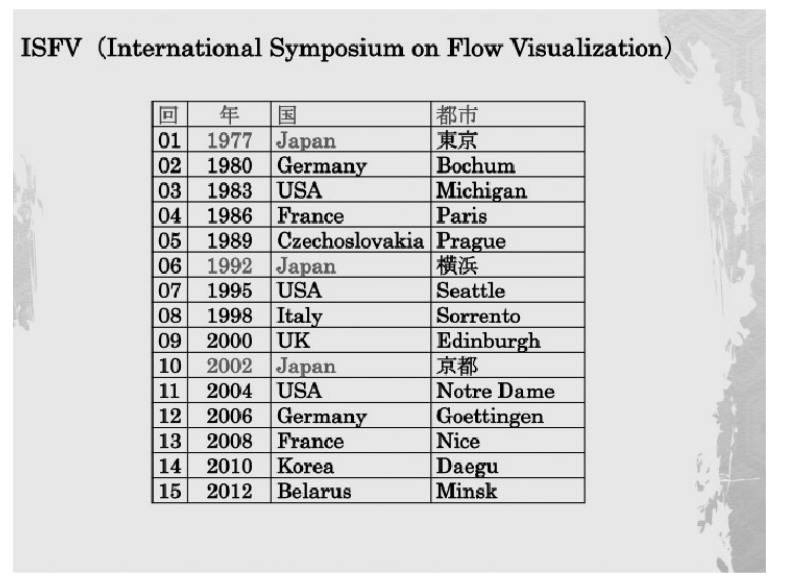

Fig.13 ISFV の歴史

りました。まあこれは,こういうアンケートをすれば大 抵，まああの，した方がいい，ということになるわけで, まあそういうのを予期してとったアンケートでございま した. 129 の回答がございまして，内 102 が積極的に開 催すべき，という結果でした。わが意を得たり，という ことで開催したわけであります。 77 年の 10 月に行いま したが，当時は 53 の論文がありまして，187 人の参加 で開催でありました， 3 年後にまた開こう，ということ も決めましたし, それから, そのために可視化情報学会, 流れの可視化学会の中に常置の委員会をおこう, という ことも決まりました。このやり方がその後の他の国際学 会にも受け継がれたように思っております。ひとつだけ， プライベートの話で恐縮ですけれども，1977 年 10 月，

私もいろんな役割を与えられて，参画をさせて頂きまし たけれど，実はその，結婚がですね，この年の 11 月で ございまして，ちょうど一か月前に国際会議で，大変あ たふたとした記憶がございます。今でも家内に言われま す (会場笑)。それから，ここに Reynolds 賞, Strouhal 賞, Leonado da Vinci 賞, Mach 賞, 浅沼賞, というふ うな賞が与えられており，それぞれの会ごとにこういう 賞を作って，常にあるのは浅沼賞でございますけれど， 出しているようでございます.

次は FLUCOME (International Conference on Fluid Control, Measurement and Visualization) です (Fig. 14). 1985 年に始まりまして，97 年とそれから来年 2013 年 奈良, これも非常に特徴のある国際会議でご ざいまして, 計測自動制御学会, 機械学会とフルードパ ワーシステム学会とが共同主催を致しまして成り立って いる学会であります.えーと時間の関係で次にいかせて 頂きます.

次はこの学会のひとつの特徴でもあります ASV (Asian Symposium on Visualization) です (Fig. 15) .Asian シンポジウムであります.すでに 11 回開催され ており, 11 回目は昨年 6 月, 新潟で開催されました. 私そのとき基調講演をするはずだったのございますけれ ど，ちょうどそのころから，体調不良に陥りまして，結

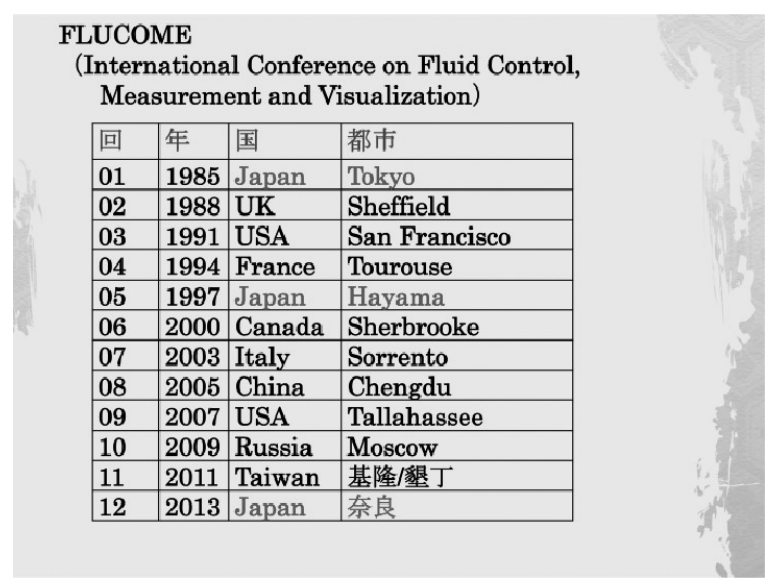

Fig.14 FLUCOME の歴史

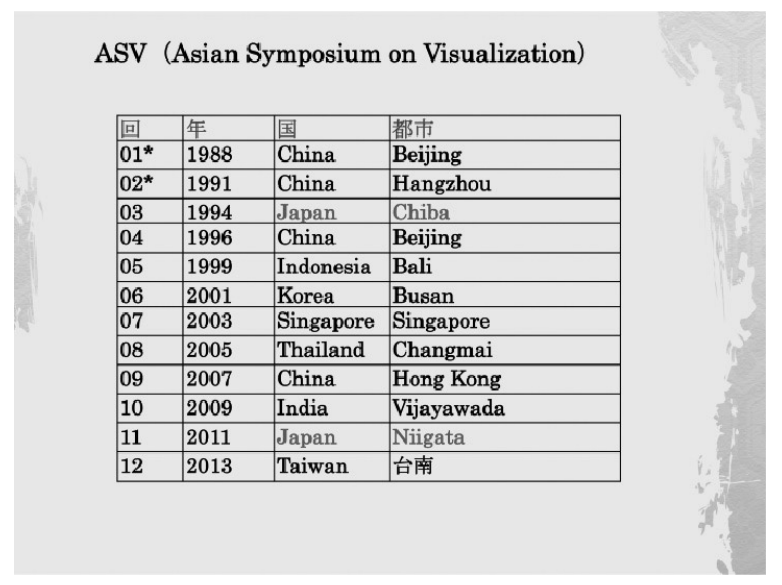

Fig.15 ASV の歴史

局 6 月の初めに入院するはめになりました. これも忘れ られない思い出でございます。このシンポジウムの特徵 はですね，さきほどの流れの可視化シンポジウムもそう でありますけれど, 準備会的なシンポジウムを開催して おります。 1 回目と 2 回目は, 日本と中国との間だけで の開催でございました．思い起こしますとですね, 1988 年が第 1 回でございますけれど，実にその 6 年前にその 動きが起こりました. その中国科学院の力学研究所の ローミンフィという先生が, 日本を学振で訪れられまし て，そのときに，流れの可視化が日本で統一的に行われ ているというのを見て，じゃあ日中でやろう，というこ とになりました。ですが，実は当時，ISFV と FLUCOME が動いておりましたので，延びに延びて 1988 年開催ということになりました.

忘れられないのは次の第 5 回のインドネシア，バリ島 で行われた大会でございました。これはその前年，1998 年に開催する予定でしたが，インドネシアの国情不安定 ということがありまして, 延期 1 年. さらにインドネシ アが，経済的に非常に困窮しておりまして，日本から相 当の援助をして開催された大会でありました。 さらにこ の大会では中国の参加者が突然キャンセルするというが ありました。これは結局来られなかった，ということ 
PIV国際ワークショップ

(International Symposium on Particle Image Velocimetry)

\begin{tabular}{|l|l|l|l|l|}
\hline 回 & 年 & Venue & & $\begin{array}{l}\text { Participants/ } \\
\text { Papers }\end{array}$ \\
\hline $01^{*}$ & 1995 & Japan & Fukui & $150 / 30$ \\
\hline $02^{*}$ & 1997 & Japan & Fukui & $112 / 33$ \\
\hline 03 & 1999 & USA & $\begin{array}{l}\text { Santa } \\
\text { Barbara }\end{array}$ & $216 / 123$ \\
\hline 04 & 2001 & Germany & Goettingen & n.a./180 \\
\hline 05 & 2003 & Korea & Busan & n.a./120 \\
\hline 06 & 2005 & USA & Pasadena & n.a./141 \\
\hline 07 & 2007 & Italy & Rome & n.a./n.a. \\
\hline 08 & 2009 & Australia & Melbourne & $200 / 157$ \\
\hline 09 & 2011 & Japan & Kobe & $200 / 133$ \\
\hline 10 & 2013 & Nederland & Delft & \\
\hline
\end{tabular}

Fig.16 PIV 国際会議の歴史

だったようですが，会場はインドネシアバリ島でござい ましたから，大変きれいで楽しませて頂きましたシンポ ジウムでありました.

次，これはPIV 国際ワークショップということです (Fig.16)，これも 1,2 回は前座的に準備シンポジウムを 福井の山本先生のところで開催して頂いて，それから国 際的な会議にしょう，ということです，昨年，震災の影 響のために神戸で開催され，それにも拘わらず成功裏に 納めさせて頂きました。

色々と調べてみたのですが，参加者数と論文数と，こ れは，国際的な基本的な数，だと思いますが，これがな かなかないです。ですから，是非これをぜひ学会の方で 整備しておいて頂きたいと思います。

流れの可視化ハンドブックにつきましては，初版と新 版がでまして，新ハンドブックというのが出る「はず」 でございます。私も編集の役割を果たすべく努力をして おりましたが，延び延びになっておりまして，これを岡 本先生にバトンタッチさせて頂きました。

最後に国際会議の数についてどうか，ということを ちょっとだけお話しさせて頂きたく思います。ICCA (International Congress and Convention Association) という組織がありまして，ここで，毎年国際会議が，世 界でいくつ, 日本でいくつ, それから各都市でいくつ, ということがいわれております。これを調べた背景は, 我が国の国力の将来に悲観的な見方が出てきておりまし て，学術会議などでも 5 年程前から，日本人学者が，日 本で開催する学術シンポジウムが減少するのではないか, という懸念を持っておりました，しかし，現実はそうで もない，ということがわかりました。これが，各国の開 催数で，これが各都市の数です (Fig.17). 国際会議が 積極的に行われておりまして, しかしある程度の数は維 持している，というのが現状であります.

最後に申し上げておきたいのは，国際会議を開くとい うことは，学会としてこれは当然必要不可欠なものであ ります。しかし，これがマンネリになっている，という 話が最近聞かれております。ぜひ可視化情報学会におか

\section{1 年に世界で開催された国際会議}

前年比 950 件增の 10,070 件

アメリカ(759 件),ドイ゙(577件)，スペイン( 463 件)，イギリス(434 件)， フランス $(428$ 件)が世界の上位 5 位

アジア圈: 中国(世界 8 位· -302 件), 暲国(世界15 位·207 件) 日本(世界13 位·233 件, 2010 年比72件减, 2010 年は世界7位)

都市別の開陮件数:

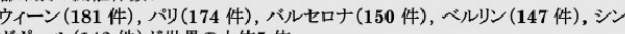
ガポール(142 件)が世界の上位5 位.

アジ圈: シンカカ゚ーール(世界5 位・142 件), 北京(10 位・111 件), 涫ル(13 位·99 件), 台北 (20 位·83 件),クアラルンフール(21 位-78 件)の順. 日本の都市: 東京(世界4 1 位·50 件), 京都 (世界69 位・29 件). 東日本大震災 の影響で、中部以東の都市では前年に比へて大幅に減少し、「西高東低」

近年, 日本の近隣諸国·地域では, 中国(北京, 上海, 杭州, 西安, 成都等), 韓 国(ソウル, 済州島, 釜山, 大邱, 大田等), 台湾(台北, 高雄等)の諸都市が, 国 際会議の開催件数の実績を上げている. 国際会議の誘致活動が世界的に熾烈に 展開されている.

Fig.17 2011 年に各国で開催された国際会議数

れましても, その目的を再認識して頂いて, 可視化情報 学会はたくさんの国際会議をやっておられて活動活発で ありますけれど，ぜひそれらを統括して頂いて，可視化 情報に関する研究の動向とか，あるいはそれを普及させ るために，当然，産業界との連携等も必要になってくる のですが，それを国際的にどういう形でやるのかという 少し戦略的な構想をお持ち頂きたい，というのを最後の 言葉とさせて頂きたいと思います。失礼致しました。

\section{5. 川橋正昭先生}

埼玉大学の川橋でございます。はじめに言い訳になっ てしまうのですが，各先生方大変立派な資料を準備され ていて，私はパネルディスカッションということで, ちょっと発言のときに参考になる程度と, 実にいい加減 なパワーポイントを作ってきてしまいました。どうかお 許しを頂きたいと思います。

私は，ここ数年の間にオフィスをいくつも閉じまして， その度に引越をするので，古い資料を全部処分してしま いました。それで今回拉話があって慌ててちょっと色々 と探しまわったんですが，なかなかきちっとした資料が ございませんで，先日実は慌てて学会事務局の方に行っ て，関連の資料を取ってきたのですが．今日お話するの に十分な資料がございませんでしたので，雑䮎な話に なってしまうと思いますが，拉許し頂きたいと思います。

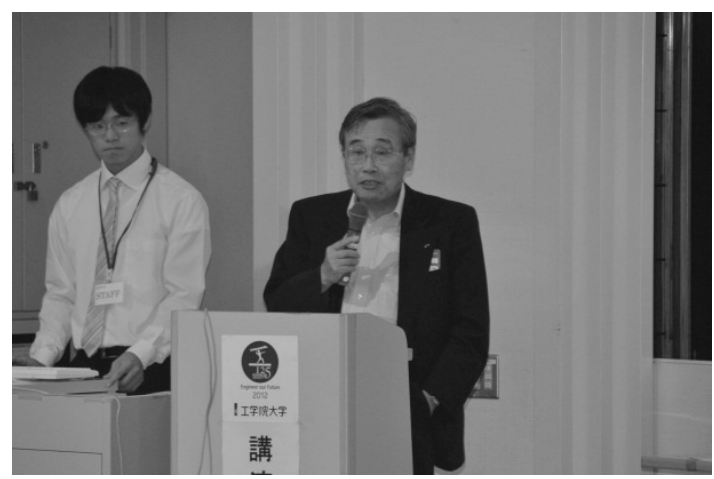

Fig.18 講演中の小林先生 
特にJOV（Journal of visualization）に関して，私が お話するのが相応しいかどうかというのが実に問題がご ざいまして，本日は，谷田先生，中山先生，小林先生が いらっしゃいますので, この先生方が中心になって育て てこられたジャーナルですので. 現在一応私がやらせて 頂いてはおりますけれども，本来でしたら，谷田先生， 中山先生，小林先生に今までの経緯をきちっとお話し頂 ければいいのではないかいう風にと思います。本日は， 現状等をちょっとご理解いただくというようなことで勘 弁して頂ければと思っております。ここ（Fig.19）にあ りますように, 可視化情報学会の英文論文集の経緯とし ましては, はじめに 1992 年頃でしたか, 確か谷田先生 を中心に，英文の論文集を発行したらどうかということ で, 委員会をおつくりになられて, 大変議論をした, と いう記録が残っていますが，それで, Progress in visualization ということで, Atlas of visualization という夕 イトルの雑誌をまとめられて, 3 回出版されております. 本来ですと, 前の先生方のように, この表紙がどうだっ たかというカラーの写真でも付けてくるべきだったんで すけど，準備不足で申し訳ございません。これが 1993 年と, 96 年, 97 年の 3 回発行されたわけでございます. 先ほどから, この学会で出版されております様々な資料 等がご報告ございましたけれど，そのなかのひとつに， 流れの可視化写真集というものがずっと出版されており まして, それが途中から英語になって, 澤田先生が編集 長になって Album of visualization というタイトルで 17 巻まで, 2000 年まで発行されていました.

Journal of visualization は, 1998 年に出版されること になりまして, 日本側ではオーム社, それから国際的に はIOS Pressに, 色々とお願いをして発行にこぎつけた ということでございます。この Journal of visualization が, Editor in Chief を中山先生, 谷田先生, 小林先生の 3 人の体制で 12 巻まで発行されたわけでございます. 平成 10 年から平成 21 年まで発行されました。この間, 先ほど申し上げました, Album of visualization が Journal of visualization に吸収され, そのジャーナルの,
Frontspiece\&Portofolio となりまして，それで, Journal of visualization がこの体制で 12 巻まで発行されたとい うことでございます。その間，私も編集委員のひとりと して，その委員会活動に参加させて頂きまして，これを 継続的に発行するのは，大変だった訳でございますが, その間の中山先生のご苦労はもう本当に言葉に尽くせな いものがあったのではないかと思います。それで色々と 努力をしながら続けて参りまして，そして，国際的にも きちっと評価されるように，定期的な発行等に努力を致 しまして，例えばインパクトファクターの評価もきちつ となされて，国際的に確立したジャーナルとなって参り ましたが，ただ，継続的に発行していくのに多くの問題 を抱えるようになりました. 従いまして, 思い切ってリ ノベーションしよう，ということで，2009 年に新しい 体制に移行する準備を致しまして，そして 13 巻から， Springer から発行される, という新たな形での再出発 をすることになりました。これが現在発行されておりま す Journal of visualization であり, 現在 15 巻になって いるわけでございます．現在の Editorial Boardの体制 はこうなっておりまして (Fig.20), 私も Editor in chief ということをさせて頂いておりますが, Associate editor, これは各世界中の地域からお願いして, このよう な方々に Associate editor をお願いしているわけでござ います。そして, Advisory boardにも，今まで，この JOVに関して，様々なご協力を頂いてきた世界中の 方々, 主要な可視化関連の研究者の方々に加わって頂い ておりまして, Advisory board を形成している，とい うのが現状でございます.

現在の状況について, 簡単にご報告させて頂きますと, リノベーションしました後, Springer から発行されて いるこの JOV に関しまして，先ほどお話しましたよう に2010 年からですが，新しい形での論文集に投稿する 論文としては，2009 年から募集を致しまして，トータ ルで, これは日々増えていますが, 7 月 5 日現在でこれ までに 330 編投稿されました。で，そのうち acceptさ れましたのが 132 編でございます。既に掲載済みが, こ

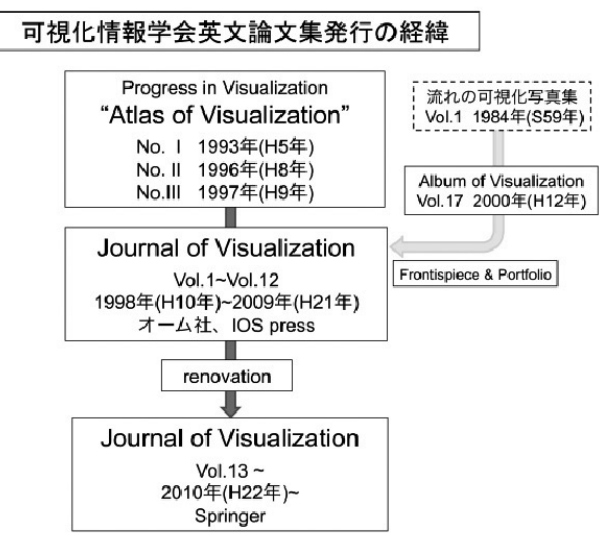

Fig.19 学会の英文論文集の歴史

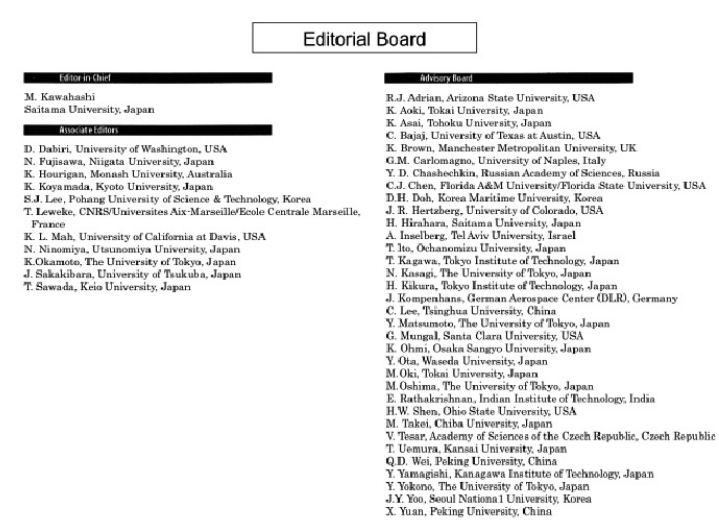

Fig.20 JOV の Editorial Board 一覧（2012 年現在） 


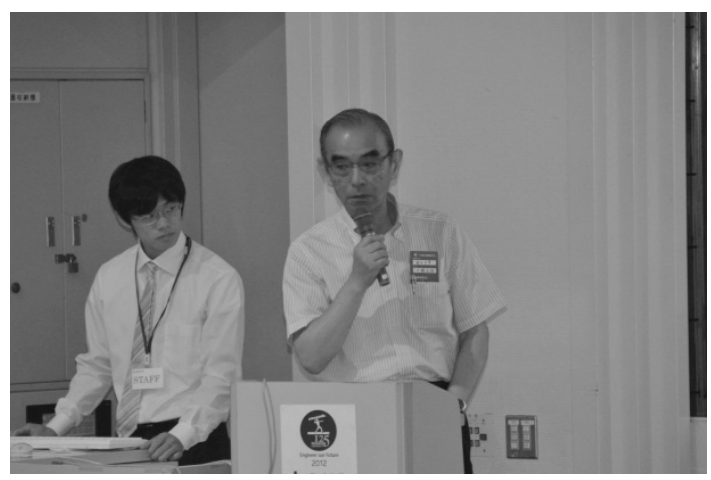

Fig.21講演中の川橋先生

の vol.15 の第 2 号までに掲載されましたのが，119編， online first で公表されて㧍りますのが 8 編，編集中が 5 編という状況でございます。また著者の修正中 11 編, 查読中 36 編という状況で, rejectされたのが 146 編で す。まあ非常に rejectの比率が高い，ということがご 覧頂けると思います。それから，取り下げ，この取り下 げというのが，色々な形がございますが，これは正式に 取り下げ，著者から取り下げられたものが5編でござい まして,まあこういう形で現在推移しております。 Accept 率が 49.5\%，ほほ半分が accepts され，半分が rejectされているということでございまして，これは， 査読が厳しいということと同時に, 論文のレベルという ことにも関連するので，まあちょっと複雑ではございま すけれども，こういうような状況であります。実はイン パクトファクターに関しましては, self citation の比率 の問題がちょっとありまして，一時評価をされておりま せんでしたが, 今年無事に復活致しまして, ごく最近で 0.435 という評価がありました。必ずしも高くはござい ませんが，インパクトファクターが復活した，というこ とでございます.

今後の課題としましては，やはり，投稿論文の質の向 上等を図っていく，ということが問題でございまして， 編集方針として，優れたレビューペーパーとか，色々な ことを考えながら，全体の論文の質の向上を図っていき たい、インパクトファクターも 1 に近いような值が取れ るような形にしていきたい，それから Short paperにつ いても，ちょっと今，どのようにしていくか，というこ との検討を進めています。それから編集体制ですが，案 外投稿件数が多いものですから, associate editorの 方々には大変ご迷惑を扔かけしていますので，こういっ た体制の整備.このようにいくつかの課題を抱えてはお りますが，今後ますます JOV が発展していくように， ご協力をお願いしたいということでございます。雑䮎な 話ではありましたが．どうもご清聴ありがとうございま した.

\section{2. 岡本孝司先生}

ただいまご紹介頂きました岡本でございます。諸先輩
Twitter の分析 （巷の興味）

2012年1月～4月末までの120日間 約4千万件の分析

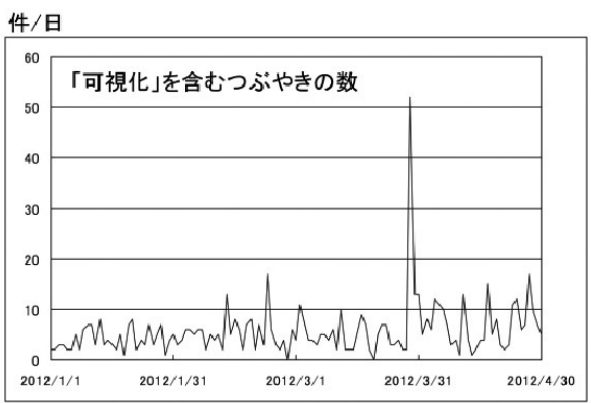

$3 / 29$ 放射能を可視化、JAXAがカメラ開発 除染に活用

Fig.22 Twitterでの「可視化」つぶやき数の推移 (2012 年 1 月〜 4 月)

方の, 大先輩方の講演の後で, 非常に䈐越ではございま すけれども，まあ，社団法人化，一般社団法人化を昨年 致しまして，1 年経って参ったわけですけれども, その 話よりも，主に今度どういう風に考えていくか，という ことについて話をしたい，というに思っています。

先程も色々話があったんですけれども，あの，ちょっ と, うちの学生にですね, 今, Twitterで「可視化」と いうキーワードがどれだけ，国語辞典に載ってないそう ですけれども，どのくらい…にしているかどうか，私も 大学で visualizationっていう講義をしますと知らない学 生が一杯いるんですけれども，どのくらい「可視化」と いのが世の中で使われているのか，というのをちょっと 調べてみました（Fig.22）。

Twitter というのは, 今若い人達で頻繁に使われてい るわけですけれども，1月から 4 月末までの 4 ケ月間, 今年です, について, 約 4000 万件, 月 1000 万件のつぶ やきを分析しまして，その中で「可視化」がどのくらい 含まれているか，というのを調べてみました，見て頂い て分かるように，一番多くても50 件しかない，まあこ れは一日あたり，ということで，トータルでも大体 600 件ぐらいという形で，600/4000 万ということで，あの， ほとんど可視化ということに関しては世の中でキーワー ド自体が使っていない，というとこでちょっと残念な状 況でございます，そのなかでも 1 日平均 10 件くらいず つはつぶやきが出てるんですけども，ピークがあるんで すけれども，これはあの，JAXA が放射能を可視化す る $\gamma$ 線， $\gamma$ カメラを開発した，というニュースがありま して，それに対してのつぶやきがいっぱい出た，という 形でピークになっているということでございます。まあ このような形で，ツイッターで巷の興味がある程度分か るのではないか，という風に思うんですが，それではこ の可視化というキーワードと共起する，つまり，一緒に つぶやきの中に入っているキーワードはどんなものが多 いのかというのをちょっと調べてみました。

大島先生が先程話されたのとちょっと関連するですけ 
れども，可視化と共起するキーワードの上位十位を並べ てみると, 残念ながらですね, 検察とか, 必要とか, 自 分とか, JAXA, 放射能, 取り調べ, JAXAは 2 回出て くるんですけれども，これは大文字と小文字でございま す。そのような形で，基本的にこれから言えるのは，可 視化というのは, あの警察の取り締まりの可視化と JAXA の放射線分布の可視化ということがメインだな, という感じで, 残念ながら流れというのはどこにも共起 してきていない, という状況でございます.

ツイッターを使っているのは主に若い人が多いという こともありますし, 研究者間ではあまりツイッター, 特 に研究情報をツイートするというのはあまりはやってな いと思いますので，そういう意味では，これはあくまで 巷の調査という形になります。これ以外のマイナーな共 起キーワードとしては, ネットであるとか, 情報である とか, プログラムであるとか, こういうようなキーワー ドもありますので, そういう意味では情報の可視化とい うか, 見える化というか, そういうところである程度の お話があるのかなあ，というように感じます。

じゃあ Twitter がそうなら Google はどうなんだろう, と思いまして, googleで「可視化」と入れて検索を やってみました Fig.23). 残念ながら 480 万件でござ います．見える化の方が 1000 万件という話でございま して，見える化の方が世の中では google 検索すると いっぱい出てくる, というような状況になっております. ただ，可視化と見える化ではですね，明らかに出てくる， まあ 20 件くらい，上位 20 件をみたのを適当に書いてみ たんですけれども, 可視化情報学会とか実は 2 位にあり ましてですね, まあ, 可視化とは, という Wikipedia の ところが一番上に来ていたですけれども，まあ可視化情 報学会もそれなりの「可視化」という分野ではプレゼン スがある，ということが分かります。で，明らかににア カデミックであるとか, 情報であるとか, そういうよう な, いわゆる技術としての可視化, というのが可視化と いうキーワードになっております。一方見える化の方は ですね，ビジネスと非常に近い関係にある。まあ，あの， ビジネスとか, 経営とか, 電力, 省エネとかいったよう な形のキーワードがあります。この中で面白いな, と

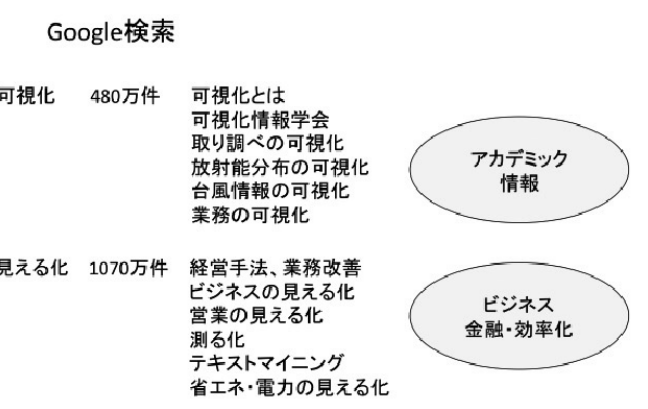

Fig.23「可視化」と「見える化」の Google 検索結果
思ったのは，見える化の中でも，測る化であるとか，テ キストマイニングであるとかですね, 少し measurement 的な，分析的なところに，見える化，ビジネスの ただ見せるのではなくて，その先の分析になっていると いう形でございます。これは, 我々, 可視化情報学会, 流れの可視化を昔からやってきたところでは，まず流れ を視る，というところから始まったんですけれども，次 に流れを視るから流れを，視た流れをどう分析していく か, まあ計測にどんどん近づいていったという，まあ計 測手法そのものになっていったということもあります。 情報の可視化においても, 今, 経営の効率化とかそうい う，「見る」形を中心にやっていますが，その見えた後 からどう分析をしていくか, という，まあいわゆる，流 れの可視化を情報の可視化がフォローアップしているよ うな印象を若干持っている，という形でございます.

次に, 色々なところで, 私の本職でありますPIV の, 本職が今最近なんなのか分からなくなってきているんで すけれども (会場笑), 本職の PIVの講演をするときに 必ず出すスライドでございまして (Fig.24), これは, ハイスピードカメラの技術マップでございます。今まで はちょっと情報系の話をしたんですけれども, 最後に計 測系, PIVの話をしたいと思います。この図は, 横軸 が 1 秒間に何フレーム取れるか, 即ちフレームレートで, 100 万コマから 1 秒に 1 コマまでがレンジスケールです. 縦軸は画素数でございまして, 現在は, 1 番上は 1600 万画素とかのデジタルカメラが普通だし, 携帯電話のな かにも 800 万とかありますけど, PIV では 100 万画素, $1000 \mathrm{k}$ くいがちょうどいいことになっています。ここ で言いたいことはですね，実は，この 1998 年から 2002 年に, 1 桁ギャップがあります。ここの 4 年間の間に, 実はですね，素子が CCD から CMOS になったことに よって，1桁，ここでイノベーションが起きている，と いう形になります。その後の 1 桁上がるのには 2011 年 までかかっていますが，10 年かかっていまして，本当 にイノベーション, CCD から CMOS になって 1 桁上 がって，そこからは後は，まあ回路や色々な工夫で,

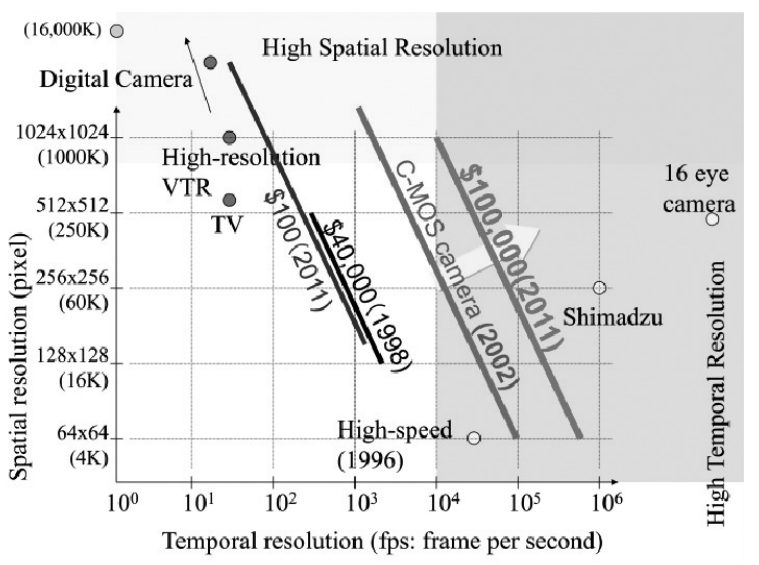

Fig.24 高速度カメラの技術開発マップ 
1000x1000 画素で毎秒 10000 コマまでいけるようになっ てきているわけです。こういうような形で, このイノ ベーションというのが，この我々の流れの可視化につい ても非常に大きなイノベーションになってきている，と いうようなところがあるのかなあ，と思っております。 ただ, 実は, この, ハイスピードカメラの歴史, まあ今 日も外にいっぱいありますけれども，やはり，我々，技 術者がですね, このハイスピードカメラの開発にも, ニーズとしてしっかり情報を言ってきたところが大きい のではないかなあというふうに思っております。10 数 年前に江藤先生が, ハイスピードカメラでどんなものを 見たいか, というアンケートを取られて，これは学会誌 にも残っていますが，というような中で，どういうハー ドを我々が欲しいのか, というのを言うと, 逆にメー カー側の方が頑張ってそれを開発してきてくれる，とい うこともあるのかなあ, というふうに思っております。 以上, 情報系といいますか, 社会から見た可視化と, そ れから，我々技術者から見た可視化のハードウェアとい う形で対比してお話させて頂きました.

次, 最後に, 学会の将来です (Fig.25). やはり可視 化情報学会は, 流体計測, 流れの可視化からスタートし てきていていますけれども，そういうような，流体計測 手法としての強みが非常にあります。今日の講演会を聴 いていても, 3 分の 1 から半数くらいは計測技術, レー ザーの可視化技術といったような形になっています。こ の標準化, 技術認証していくということ, それから, さ らにはPIVの計測データを, 本当に精度保証してやる 必要があると思います。 今のところ, まあ定量的なデー 夕は出るんですけれども, ある程度の, まだ誤差が大き い状況での議論しかできていません。そこをやはり精度 保証をして, PIV データが, シミュレーションと 1 対 1 くらいの精度で議論できるようにやっていきたい. そ れから, 先ほどブレイクスルーの話をしましたけれども, このレーザー計測に関して, 何らかのブレイクスルーが 必要であろうと思われます。この部分を学会として伸ば していくことが重要かと思うわけです。それから, 情報 の可視化のパイオニア，これまでに 10 年くらい情報の 可視化の技術をやってきていますけれども，世の中がよ うやく近づいて, ビジネスとしても近づいてきた，と

\section{可視化情報学会の将来}

・流体計測手法としての強みを伸ぱす - PIVの標準化、技術認証

- PIV計測データの定量的な精度保証

ーレーザ計測技術のブレークスルー

・情報可視化パイオニアとして深化

一情報可視化の標準化、技術認証

一情報提示手段のキラーアプリ開発

-アプリケーション発掘とビジネス展開

Fig.25 学会の将来に向けての課題

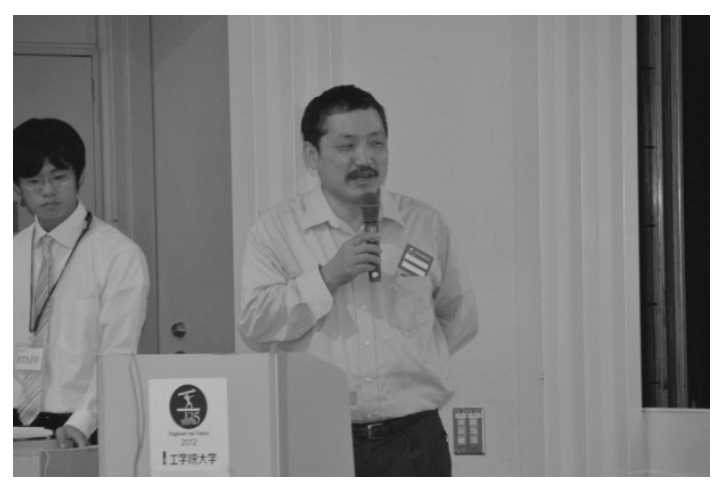

Fig.26 講演中の岡本先生

思っておりますので, やはりこちらも標準化が重要かと. それからやはりキラーアプリ的なものが必要だと思いま す．特にアプリケーションの発掘とビジネス展開, こち らに向けてむけて情報の可視化をやっていければ, やっ ていかなくちゃいけないなあ, という風に思っていると ころでございます.

次は最後なんですけど, 国際展開を, というのもやは り, 今日もこれまで, 小林先生をはじめですね, 川橋先 生をはじめ, 先生方がずっと言われてきておりますけれ ども，国際展開を是非進めていきたい。 それが可視化情 報学会の強みであろう, という風に思っております. ちょうど零秒になるところぐらいですかね. どうもあり がとうございました。 